\title{
Pendeteksian Kerusakan Printer menggunakan Metode Forward Chaining
}

\author{
Amriana Amriana a,1, Albrecht Yordanus Erwin Dodu a,2 dan Pebri Ramadhan Mas a,3,* \\ ${ }^{a}$ Teknologi Informasi, Fakultas Teknik, Universitas Tadulako, Jl. Soekarno Hatta No.KM. 9, Tondo, Palu, 94148, Indonesia \\ ${ }^{1}$ amrianaa23@gmail.com; ${ }^{2}$ ayerwin.dodu@gmail.com; ${ }^{3}$ pebriramadhanmas@gmail.com \\ * corresponding author
}

\begin{abstract}
INFORMASI ARTIKEL ABSTRAK
Dikirim: 16 Februari 2020

Diulas: 31 Maret 2020

Direvisi: 9 April 2020

Diterbitkan: 27 April 2020

\section{Kata Kunci:}

Printer

Forward Chaining

Sistem Pakar

Depth First Search

Gejala

Seiring perkembangan teknologi informasi yang sangat maju, hampir setiap kalangan memiliki printer di kediamanya sebagai alat bantu cetak. Namun tidak sedikit printer yang mengalami masalah ringan maupun berat. Dengan perkembangan teknologi yang maju ini pula di ikuti dengan hampir seluruh kalangan memiliki smarphone pribadi. Penelitian ini bertujuan untuk membangun sebuah sistem berbasis mobile dimana user dapat mendeteksi kerusakan yang dialami printernya dengan menggunakan aplikasi di smartphone miliknya berdasarkan pengetahuan yang di dapat dari pakar yang di buat dengan metode Forward Chaining. Sistem pakar ini dapat mendeteksi sembilan jenis printer yang berbeda milik pabrikan canon dengan total 26 kerusakan dan 38 gejala serta memiliki tingkat akurasi sekitar $80 \%$.
\end{abstract}

\section{Keywords:}

Printer

Forward Chaining

Expert System

Depth First Search

The Symptoms

\section{ABSTRACT}

As technology advances, almost everyone has a printer in their home as a printing aid. but not a few printers that have small or big problems. with this technological advancement, almost all people have personal smarthpones. This research aims to build a moble based system where users can solve printer problems by using applications on their smartphones based on knowledge obtained from experts created by the Forward Chaining method. This expert system can detect nine different types of printers owned by Canon manufacturers with total of 26 Problem and 38 symptomps and has an $80 \%$ of accuracy.

This is an open access article under the CC-BY-SA license.

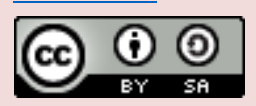

\section{Pendahuluan}

Seiring perkembangan teknologi informasi yang sangat maju dan cukup pesat di Indonesia, hampir semua kalangan memiliki printer sebagai alat bantu yang di gunakan sebagai media cetak, sehingga keberadaan printer di dalam rumah sudah tidak asing lagi di masyarakat Indonesia yang efisien dalam membantu proses pengerjaan. Namun tidak sedikit printer yang mengalami masalah, baik ringan maupun berat serta memerlukan biaya yang tidak sedikit. Masyarakat saat ini masih awam jika di hadapkan dengan kerusakan printer. sedangkan kerusakan tersebut membutuhkan penanganan yang tepat serta benar. Penanganan kerusakan perangkat keras printer membutuhkan seorang ahli di bidangnya, proses diagnosa printer harus melalui pemeriksaan secara mendalam dan berurutan.

Pada penelitian ini, data yang di gunakan berdasarkan pakar, yang di bagun menjadi sebuah system, peran system pakar sangat penting, dikaranakan sebuah system tidak akan mengalami penuaan, atau hilangnya ingatan, ini berbanding terbalik terhadap pakar itu sendiri dimana orang yang pakar dalam suatu hal lama kelamaan ingatanya akan menurun, kemudian umurnya akan berkurang, jika ilmu pakar ini tidak di dokumentasikan kedalam sebuah system, maka pengetahuan yang dimiliki oleh pakar tersebut akan hilang.

Dalam penelitianya, Nugraha (2015) membuat Sistem Pakar Untuk Mendiagnosa Kerusakan Perangkat Televisi Menggunakan Metode Backward Chaining. Tujuan penelitian ini adalah merancang dan membangun system pakar yang dapat mendiagnosa kerusakan pada perangkat televisi berdasarkan ciri kerusakan yang ada dengan menggunakan metode Backward Chaining. Persamaan penelitian ini dengan penelitian yang sedang dilakukan penulis yaitu sama-sama mendiagnosa masalah kerusakan perangkat keras dan menggunakan pakar dalam pengambilan hasil diagnosanya. Perbedaannya terletak pada algoritma yang 
di gunakan, dimana penulis menggunakan Forward Chaining karena untuk melakukan pendeteksian di butuhkan informasi gejala terlebih dahulu untuk mencapai kesimpulan [1].

Dalam penelitiannya, Supartini (2016) membuat aplikasi identifikasi dini penyakit Tuberkulosis (TB) menggunakan metode Forward Chaining. Penelitian ini bertujuan untuk mengidentifikasi adanya penyakit Tuberkulosis (TB) pada manusia berdasarkan gejala utama, hasil laboratorium dan hasil rontgen. Persamaan penelitian ini dengan penelitian yang sedang dilakukan penulis yaitu keduanya menggunakan algoritma Forward Chaining. Dalam penelitianya sistem tersebut dapat mendiagnosa dini penyakit Tuberkolosis, berbeda dengan penulis yang membahas tentang pendeteksian kerusakan printer [2].

Dalam penelitiannya, Hartono dan Irsyad (2016) membuat aplikasi pendeteksi kerusakan printer berbasis web dengan menggunakan metode Forward Chaining. Hasil dari penelitian ini adalah sebuah sistem aplikasi yang dapat membantu masyarakat dalam pendeteksian kerusakan printer secara dini. Persamaan penelitian ini dengan penelitian yang dilakukan penulis yaitu menggunakan algoritma Forward Chaining dan untuk perbedaannya terletak pada jumlah printer, gejala serta kerusakan yang bias di tangani, yang hanya menghasilkan 15 gejala serta 6 kerusakan dengan 3 jenis printer, sedangkan yang penulis buat dapat mendiagnosa 26 kerusakan dengan gejala berjumlah 38 serta dapat mendiagnosa 9 jenis printer yang berbeda. Perbedaan selanjutnya terletak pada platform yang berbeda pada penelitian ini aplikasi yang di bangun berbasis web, sedangkan aplikasi yang akan di bangun oleh penulis berbasis android [3].

Dalam penelitiannya, Anggraeni (2017) membuat aplikasi sistem pakar untuk mendiagnosa kerusakan printer. Printer adalah sebuah alat untuk mencetak sebuah file menjadi sebuah dokumen, oleh karena itu jenis printer tidak hanya satu saja tetapi banyak berbagai merk dan tipe. Oleh Karena itu sangat mengkhawatirkan apabila printer banyak mengalami kerusakan total tetapi tidak dapat memperbaiki dengan benar atau malah secara otodidak, seperti tukang service yang mampu memperbaiki printer secara otodidak saja dan tidak langsung berkonsultasi ke pakarnya. Namun semua hal itu dapat diatasi dengan adanya sistem pakar yang dapat mendiagnosa 25 kerusakan yang berasal dari 17 gejala yang berbeda. Sistem pakar ini dibangun menggunakan kombinasi teknologi web populer terbaru yaitu PHP, HTML, CSS, jQuery dan MySQL. Persamaan dari penelitian ini dengan penelitian yang akan penulis buat yaitu sama-sama mendeteksi kerusakan pada Printer, akan tetapi printer yang di diagnosa hanya canon IP 2770 sedangkan penulis dapat mendiagnosa 9 jenis printer berbeda dan yang membedakan selanjutnya penelitian ini dan penelitian yang akan penulis buat adalah penelitian ini menggunakan metode Certainty Factor Pararel, sedangkan penulis menggunakan metode Forward Chaining [4].

Berdasarkan hasil survei yang penulis lakukan di CV. Speed Computer Palu yang menyediakan jasa perbaikan printer bahwa printer yang di perbaiki menggunakan prosedur standar perbaikan berdasarkan pengalaman pakar teknisi printer yang bersangkutan sehingga ketika pakar teknisi tidak berada di tempat atau sedang melakukan perjalanan jauh, maka penanganan di berikan ke teknisi lain dan biasanya teknisi lain belum bisa menanganinya sehingga mengakibatkan keterlambatan dan complain dari pelanggan.

Untuk dapat mengatasi permasalahan yang telah dipaparkan di atas, maka dibutuhkan aplikasi sistem pakar menggunakan algoritma Forward Chaining yang dapat mendeteksi kerusakan printer yang akan di perbaiki. Sehingga penulis merancang penelitian berkaitan dengan pendeteksian kerusakan printer berjudul: Sistem pakar pendeteksian kerusakan printer menggunakan metode Forward Chaining (Studi Kasus: CV. Speed Komputer).

\section{Metode}

\section{A. Forward Chaining}

Forward Chaining merupakan salah satu teknik yang digunakan dalam mekanisme inferensi untuk pengujian aturan. Dalam Forward Chaining kerusakan printer ini, aturan-aturan yang dimasukan oleh pengguna akan diuji satu demi satu oleh sistem dalam urutan tertentu. Urutan itu berupa urutan pemasukan aturan ke dalam basis data aturan. Setiap aturan diuji, sistem pakar akan mengevaluasi apakah kondisinya benar atau salah. Jika kondisinya benar, maka aturan itu disimpan kemudian aturan berikutnya diuji. Sebaliknya, jika kondisinya salah maka aturan itu tidak disimpan dan aturan berikutnya diuji.

Proses ini akan berulang (iterative) sampai seluruh basis aturan teruji dengan berbagai kondisi sehingga menghasilkan kesimpulan kerusakan. Kelebihan dari metode Forward Chaining adalah data baru dapat dimasukkan ke dalam tabel database inferensi dan kemungkinan untuk melakukan perubahan inference rules.

Pada inferensi dengan metode Forward Chaining penelusuran akan dimulai dari anteseden yaitu permasalahan yang dihadapi. Pemrosesan akan merupakan serangkaian konsekuensi berupa irisan permasalahan dengan penyebab dan perbaikannya. Metode inferensi Forward Chaining disebut juga data driven, dimulai dengan fakta-fakta dan menelusuri aturan-aturan yang sesuai sampai diperoleh kesimpulan. Model dari sistem Forward Chaining dapat dilihat pada Gambar 1. 


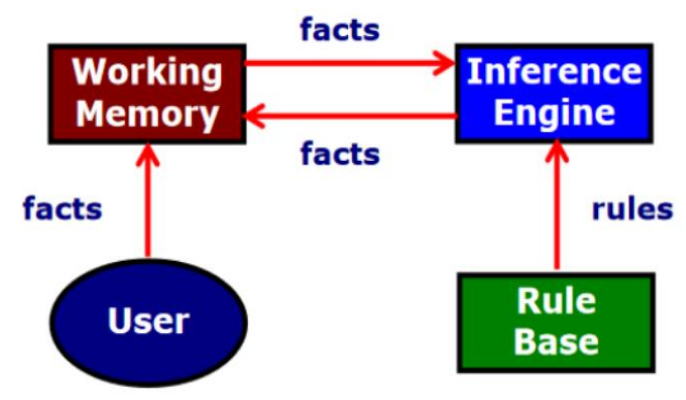

Gambar 1. Model Sistem Forward Chaining [5].

\section{B. Perbedaan Forward Chaining dan Backward Chaining}

Perbedaan Backward Chaining dan Forward Chaining adalah sebagai berikut [6]:

- Eksplorasi dari pengetahuan memiliki mekanisme yang berbeda antara Forward Chaining dan Backward Chaining. Backward Chaining lebih terfokus dan mencoba untuk menghindari eksplorasi jalur-jalur yang tidak perlu dari reasoning. Sementara Forward Chaining seperti pencarian yang melelahkan

- Backward Chaining baik untuk tugas-tugas klasifikasi dan diagnosa, tetapi tidak cukup baik untuk perencanaan, perancangan, dan pemantauan proses. Namun Forward Chaining cocok untuk tugastugas tersebut

- Forward Chaining sistem melibatkan penulisan rule-rule untuk mengatur sub goal-sub goal. Sementara Backward Chaining secara otomatis mengatur sub goal-sub goal.

C. System Pakar dan Strukturnya

Sistem pakar adalah program komputer yang merupakan cabang dari penelitian dari ilmu komputer yaitu kecerdasan buatan [7]. Sistem pakar berusaha mengadopsi pengetahuan manusia ke computer, agar Komputer dapat menyelesaikan masalah seperti biasa yang dilakukan oleh para ahli. Sistem pakar pada penelitian ini akan diaplikasikan pada aplikasi berbasis android menggunakan Hypertext Preprocessor [8], CSS, serta HTML kemudian di buat dalam bentuk aplikasi mobile menggunakan Android Studio, dengan informasi yang di sajikan dalam bentuk aplikasi mobile, kemudian data yang tersimpan di masukan kedalam basis data [9] MySQL yang merupakan RDBMS yang cepat dan mudah di gunakan [10].

Pada umumnya, antar muka pemakai juga berfungsi untuk menginputkan pengetahuan baru kedalam basis pengetahuan sistem pakar, menampilkan fasilitas penjelasan sistem dan memberikan tuntunan penggunaan sistem secara menyeluruh langkah demi langkah sehingga pemakai mengerti apa yang harus dilakukan terhadap sistem. Struktur sistem pakar dapat dilihat pada Gambar 2.

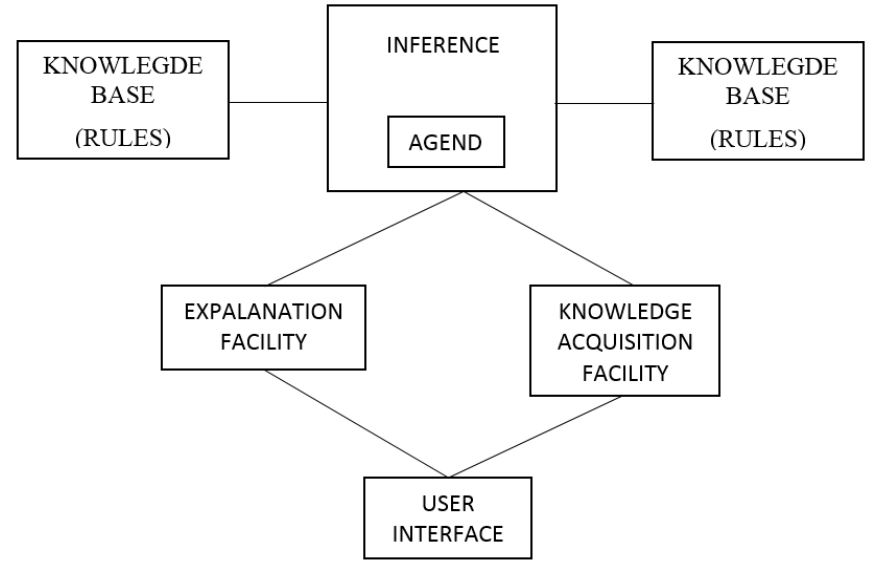

Gambar 2. Struktur Sistem Pakar [11]

D. Konsep Dasar Fungsi Sistem Pakar

Sistem pakar adalah salah satu cabang dari Artificial Intelligence (AI) yang membuat penggunaan secara luas knowledge yang khusus untuk penyelesaian masalah tingkat manusia yang pakar dalam suatu bidang. Dalam tulisan ini pakar yang di maksudkan adalah orang yang mempunyai keahlian dalam bidang perbaikan printer, yaitu pakar yang mempunyai knowledge atau kemampuan khusus yang orang lain tidak mengetahui atau mampu dalam bidang yang dimilikinya. Konsep dasar sistem pakar dapat terlihat pada Gambar 3 . 


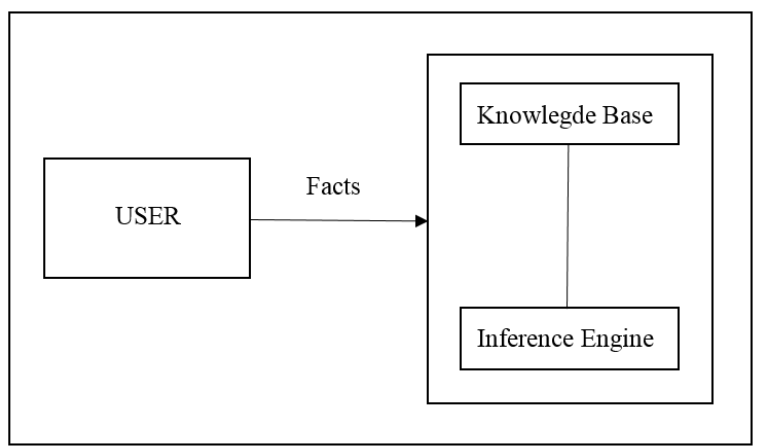

Gambar 3. Konsep dasar fungsi sistem pakar [12].

\section{E. Metode Forward Chaining}

Forward Chaining adalah tehnik pencarian yang dimulai dengan fakta yang diketahui, kemudian mencocokan fakta -fakta tersebut dengan bagian IF dari rules IF-THEN. Bila ada fakta yang cocok dengan bagian IF, maka rule tersebut dieksekusi. Bila sebuah rule dieksekusi, maka sebuah fakta baru (bagian THEN) ditambahkan ke dalam database [13],

F. Pseudocode Forward Chaining

Repeat

Pseudocode untuk rancangan algoritma Forward Chaining sebagai berikut [14] :

for each indikasi do

if indikasi $=$ rule indikasi then

next rule indikasi

else

next indikasi

end if

end for

until kerusakan ditemukan

G. Metode Pencarian Depth-First Search (DFS)

Untuk mendapatkan hasil yang diinginkan oleh user, sistem pakar menggunakan metode pencarian diantaranya adalah Depth first search. Algoritma Depth First Search (DFS) merupakan metode pencarian sistematis buta yang melakukan ekpansi sebuah path (jalur) menuju penyelesaian masalah sebelum melakukan ekplorasi terhadap path yang lain. Proses searching mengikuti sebuah path tunggal sampai menemukan goal atau dead end. Apabila proses searching menemukan dead-end, DFS akan melakukan penelusuran balik ke node terakhir untuk melihat apakah node tersebut memiliki path cabang yang belum dieksplorasi.

Pada algoritma ini setiap gejala di misalkan node-node, kemudian akhir dari node adalah kerusakan(kesimpulan) yang di maksudkan, sehingga dapat di misalkan untuk mencapai node akhir D, di butuhkan node-node penghubung lainya seperti A-B-C = D artinya untuk mendapatkan nilai kesimpulan D, dibutuhkan gejala yang benar A,B, serta C.

Kelebihan DFS terletak pada jumlah memori yang diigunakan untuk melakukan komputasi sedikit, karena cukup satu node yang diingat untuk menjelajah isi pohon, yaitu node yang sedang digunakan. Pencarian dengan Algoritma DFS juga memiliki kelemahan, yaitu solusi yang ditemukan tidak selalu optimal, karena yang didahulukan dalam pencarian adalah menuruni pohon. Berikut adalah contoh representasi DFS dalam bentuk pohon pencarian graf pada Gambar 4.

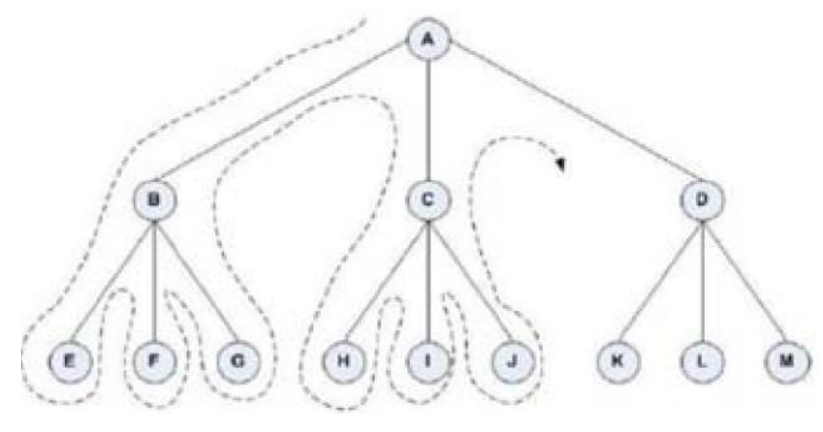

Gambar 4. Diagram Pohon DFS [10] 


\section{Hasil dan Pembahasan}

Hasil dari penelitian ini adalah system pakar diagnosa kerusakan printer menggunakan metode Forward Chaining. Prosedur yang di lakukan di awal pada sistem ini adalah admin atau pakar memasukan informasi gejala-gejala, jenis kerusakan, sebab dan solusi perbaikan printer sesuai dengan sembilan tipe printer Canon: ip2770, Mp 258, Mp287, Mp237, Ip1980, Ip1880, Ix 4000, Ix 5000, Ix 6000. Tabel 1 memperlihatkan gejalagejala yang di gunakan untuk mendiagnosa kerusakan printer.

Tabel 1. Tabel Gejala-gejala

\begin{tabular}{|c|c|}
\hline \multicolumn{2}{|r|}{ Gejala-Gejala } \\
\hline Id & Gejala \\
\hline G0001 & $\begin{array}{l}\text { Apakah tipe printer anda termasuk di tipe seperti berikut (Canon ip 2770, } \\
\text { Canon Mp 258, Canon Mp 287, Canon Mp 237) }\end{array}$ \\
\hline G0002 & Apakah printer anda termasuk tipe (Canon Ip 1980, Canon Ip 1880) \\
\hline G0003 & $\begin{array}{l}\text { Apakah printer anda termasuk tipe (Canon Ix 4000, Canon Ix 5000, Canon } \\
\text { Ix 6000) }\end{array}$ \\
\hline G0004 & Printer berhasil menarik kertas \\
\hline G0005 & Printer mencetak tapi hasil kosong \\
\hline G0006 & Cetakan tidak lengkap dengan karakter aneh \\
\hline G0007 & Cetakan kabur / bergaris \\
\hline G0008 & Salah satu warna atau lebih tidak keluar \\
\hline G0009 & Cetakan bagus tapi tabel atau garis lurus tercetak miring atau tidak rapi \\
\hline G0010 & Printer gagal menarik kertas \\
\hline G0012 & $\begin{array}{l}\text { Kertas tertarik miring atau tersangkut setengah dan menampilkan E03 pada } \\
\text { printer dengan panel LED }\end{array}$ \\
\hline G0013 & Printer blink $5 \mathrm{x}$ orange $1 \mathrm{x}$ hijau atau blink $7 \mathrm{x}$ orange dan $1 \mathrm{x}$ hijau \\
\hline G0014 & Printer menampilkan tampilan LED E04 atau E05 atau E07 \\
\hline G0015 & $\begin{array}{l}\text { Printer blink 13x / 16x orange dan 1x hijau, atau menampilkan LED E13 / } \\
\text { E16 }\end{array}$ \\
\hline G0016 & $\begin{array}{l}\text { Printer Blink 4x Orange 1x blink hijau / 7x bink bergantian / 8x blink } \\
\text { orange 1x blink hijau }\end{array}$ \\
\hline G0017 & Printer menampilkan LED E08/P07 \\
\hline G0018 & Printer bisa menarik kertas dengan baik \\
\hline G0019 & Printer mencetak tapi hasil tidak terlihat \\
\hline G0020 & Cetakan tidak lengkap dengan karakter tidak sesuai \\
\hline G0021 & Cetakan terlihat kabur / bergaris \\
\hline G0022 & Salah satu warna atau lebih tidak keluar \\
\hline G0023 & Cetakan bagus tapi tabel atau garis lurus tercetak miring atau tidak rapi \\
\hline G0024 & Printer gagal menarik kertas \\
\hline G0025 & $\begin{array}{l}\text { Kertas tertarik miring atau tersangkut setengah dan lampu indikator } \\
\text { menyala } 3 \mathrm{x} \text { orange dan } 1 \mathrm{x} \text { hijau }\end{array}$ \\
\hline G0026 & Printer Blink 5/7x Orange 1x hijau \\
\hline G0027 & Printer blink $13 \mathrm{x} / 16 \mathrm{x}$ orange dan $1 \mathrm{x}$ hijau \\
\hline G0028 & Printer blink $4 \mathrm{x} / 8 \mathrm{x}$ orange $1 \mathrm{x}$ hijau \\
\hline G0029 & Printer A3 berhasil menarik kertas \\
\hline G0030 & Hasil tidak ada atau kosong \\
\hline G0031 & Karakter aneh muncul / simbol-simbol bermunculan \\
\hline G0032 & Cetakan kabur serta hasil bergaris (Cetakan tidak sempurna) \\
\hline G0033 & Warna ada yang tidak keluar (tidak lengkap) \\
\hline G0034 & Printer tidak bisa menarik kertas \\
\hline G0035 & Printer Blink 3 kali \\
\hline G0036 & Printer Blink 4 kali \\
\hline G0037 & Printer Blink 7 kali \\
\hline G0038 & Printer Blink 9 kali \\
\hline G0039 & Printer Blink 14 kali \\
\hline
\end{tabular}


Pada penelitian ini dari Sembilan jenis printer yang ada di dapatkan 39 gejala-gejala berbeda yang di peroleh dari pakar. Pada Tabel 2 memperllihatkan aturan-aturan yang berlaku untuk mencapai kerusakan yang ada pada printer.

Tabel 2. Tabel Aturan-aturan

\begin{tabular}{|c|c|c|}
\hline \multicolumn{3}{|r|}{ Aturan - aturan (Rule) } \\
\hline Kerusakan & Aturan/rule & Keterangan \\
\hline $\mathbf{P 1}$ & G1,G4,G5 & Tinta habis \\
\hline $\mathbf{P 2}$ & G1,G4,G6 & Driver bermasalah \\
\hline P3 & G1,G4,G7,G8 & Cartridge bermasalah \\
\hline P4 & G1,G4,G9 & Sensor panjang bermasalah \\
\hline P5 & G1,G10,G11 & Paper Jammed / kertas macet \\
\hline P6 & G1,G10,G12 & Salah satu Cartrige atau keduanya tidak terbaca \\
\hline P7 & G1,G10,G13 & Cartridge tidak di temukan \\
\hline P8 & G1,G10,G14 & "Ink Has Run Out" \\
\hline P9 & G1,G10,G15 & Printer perlu di reset \\
\hline P10 & G1,G10,G16 & Mesin printer anda perlu di reset menggunakan program \\
\hline P11 & G2,G17,G18 & Tinta didalam cartridge habis \\
\hline P12 & G2,G17,G19 & $\begin{array}{l}\text { Driver penghubung antara printer dan komputer mengalami } \\
\text { masalah }\end{array}$ \\
\hline P13 & $\mathrm{G} 2, \mathrm{G} 17, \mathrm{G} 20,21$ & Cartridge buntu atau kekurangan tinta \\
\hline P14 & $\mathrm{G} 2, \mathrm{G} 17, \mathrm{G} 22$ & $\begin{array}{l}\text { Sensor transparan berukuran panjang di dekat head } \\
\text { bermasalah }\end{array}$ \\
\hline P15 & $\mathrm{G} 2, \mathrm{G} 23, \mathrm{G} 24$ & Mekanik printer bermasalah \\
\hline P16 & G2,G23,G25 & cartrige tidak terbaca salah satu atau keduanya \\
\hline P17 & $\mathrm{G} 2, \mathrm{G} 23, \mathrm{G} 26$ & "Ink Has Run Out” \\
\hline P18 & $\mathrm{G} 2, \mathrm{G} 23, \mathrm{G} 27$ & Mesin printer anda perlu di reset menggunakan program \\
\hline P19 & G3,G28,G29 & Tinta didalam cartridge kosong \\
\hline $\mathbf{P 2 0}$ & $\mathrm{G} 3, \mathrm{G} 28, \mathrm{G} 30$ & Driver bermasalah printer A3 canon bermasalah \\
\hline $\mathbf{P 2 1}$ & $\mathrm{G} 3, \mathrm{G} 28, \mathrm{G} 31, \mathrm{G} 32$ & Cartridge mengalami bermasalah \\
\hline $\mathbf{P 2 2}$ & G3,G33,G34 & Kertas nyangkut (Paper jam) \\
\hline $\mathbf{P 2 3}$ & G3,G33,G35 & Tinta kosong atau tinta tidak di isi di cartridge \\
\hline $\mathbf{P 2 4}$ & G3,G33,G36 & "Multiple ink tanks of the same color installed" \\
\hline $\mathbf{P} 25$ & G3,G33,G37 & Printer tidak bisa membaca kamera \\
\hline P26 & G3,G33,G38 & Ink tank not recognized \\
\hline
\end{tabular}

Dalam proses mengacu pada pohon pencarian keputusan berdasarkan konsep Depth First Search yang setiap gejala di masukan oleh pengguna akan di perikasa oleh pohon pencarian yang kemudian aturan terpenuhi dan secara terus menerus sampai di dapatkan keputusan. Berdasarkan tabel aturan diatas maka pohon penelusuran gejala yang dapat terbentuk seperti pada Gambar 5 dimana proses penelusuran dimulai dari indeks tertinggi ke indeks terendah menghasilkan kesimpulan.

Pengaplikasian Forward Chaining pada penelitian yang dilakukan dengan cara memasukan aturan IFTHEN, dimana IF merupakan informasi masukan atau gejala, sedangkan THEN merupakan konklusi atau kesimpulan(kerusakan). Tabel 3 menampilkan aturan gejala kerusakan yang dibuat untuk mendiagnosa kerusakan printer.

Bentuk umum:

IF Gejala A AND Gejala B AND ... AND Gejala X THEN Kesimpulan 


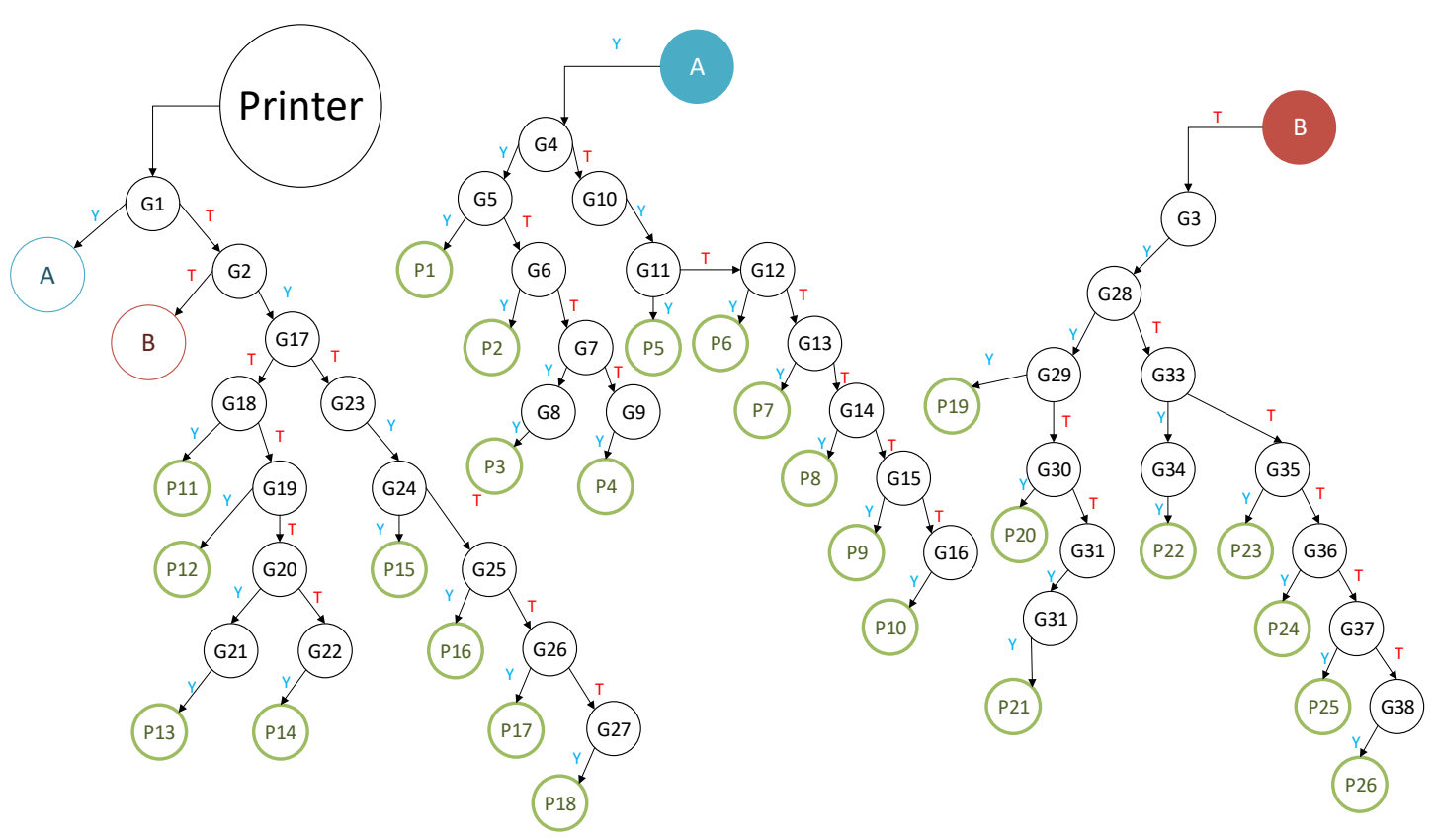

Gambar 5. Diagram Pohon DFS

Tabel 3. Aturan Gejala Kerusakan

\begin{tabular}{cl}
\hline \multirow{2}{*}{ No. } & \multicolumn{1}{c}{ Aturan Gejala Kerusakan } \\
\cline { 2 - 3 } & \multicolumn{1}{c}{ Aturan } \\
\hline 1 & IF printer termasuk Canon ip 2770, Canon Mp 258, Canon Mp 287, Canon Mp 237 \\
& AND printer berhasil menari kertas AND printer mencetak tapi hasil kosong, THEN \\
& Tinta habis
\end{tabular}

$2 \quad I F$ printer termasuk Canon ip 2770, Canon Mp 258, Canon Mp 287, Canon Mp 237 $A N D$ printer berhasil menari kertas $A N D$ cetakan lengkap dengan hasil aneh THEN Driver bermasalah

3 IF printer termasuk Canon ip 2770, Canon Mp 258, Canon Mp 287, Canon Mp 237 $A N D$ cetakan kabur atau bergaris $A N D$ salah satu warna atau lebih bermasalah THEN cartridge bermasalah

$4 \quad I F$ printer termasuk Canon ip 2770, Canon Mp 258, Canon Mp 287, Canon Mp 237 $A N D$ printer berhasil menari kertas $A N D$ cetakan bagus tapi tabel atau garis lurus tercetak miring atau tidak rapi THEN sensor panjang bermasalah

$5 \quad I F$ printer termasuk Canon ip 2770, Canon Mp 258, Canon Mp 287, Canon Mp 237 $A N D$ printer gagal menari kertas $A N D$ Kertas tertarik miring atau tersangkut setengah dan menampilkan E03 pada printer dengan panel LED THEN paper jammed / kertas macet

$6 \quad$ IF printer termasuk Canon ip 2770, Canon Mp 258, Canon Mp 287, Canon Mp 237 $A N D$ printer gagal menari kertas $A N D$ Printer blink 5x orange 1x hijau atau blink 7x orange dan 1x hijau THEN Salah satu Cartrige atau keduanya tidak terbaca

$7 \quad I F$ printer termasuk Canon ip 2770, Canon Mp 258, Canon Mp 287, Canon Mp 237 $A N D$ printer gagal menari kertas $A N D$ Printer menampilkan tampilan LED E04 atau E05 atau E07 THEN cartrige tidak ditemukan

8 IF printer termasuk Canon ip 2770, Canon Mp 258, Canon Mp 287, Canon Mp 237 $A N D$ printer gagal menari kertas $A N D$ Printer blink 13x / 16x orange dan 1x hijau, atau menampilkan LED E13 / E16 THEN "Ink Has Run Out”

$9 \quad I F$ printer termasuk Canon ip 2770, Canon Mp 258, Canon Mp 287, Canon Mp 237 $A N D$ printer gagal menari kertas $A N D$ Printer Blink 4x Orange 1x blink hijau / 7x bink bergantian / 8x blink orange 1x blink hijau THEN Printer perlu di reset

10 IF printer termasuk Canon ip 2770, Canon Mp 258, Canon Mp 287, Canon Mp 237 $A N D$ printer gagal menari kertas AND Printer menampilkan LED E08/P07 THEN Mesin printer anda perlu di reset menggunakan program

11 IF printer termasuk Canon ip 1980 dan Canon ip 1880 AND Printer bisa menarik 
kertas dengan baik $A N D$ Printer mencetak tapi hasil tidak terlihat THEN tinta di cartrige telah habis

12 IF printer termasuk Canon ip 1980 dan Canon ip 1880 AND Printer bisa menarik kertas dengan baik AND Cetakan tidak lengkap dengan karakter tidak sesuai THEN Driver penghubung antara printer dan komputer mengalami masalah

13 IF printer termasuk Canon ip 1980 dan Canon ip 1880 AND Printer bisa menarik kertas dengan baik $A N D$ Cetakan terlihat kabur / bergaris $A N D$ salah satu warna atau lebih tidak keluar THEN cartridge buntu atau kekurangan tinta

$14 I F$ printer termasuk Canon ip 1980 dan Canon ip 1880 AND Printer bisa menarik kertas dengan baik $A N D$ Cetakan bagus tapi tabel atau garis lurus tercetak miring atau tidak rapi THEN Sensor transparan berukuran panjang di dekat head bermasalah

$15 I F$ printer termasuk Canon ip 1980 dan Canon ip 1880 AND Printer gagal menarik kertas $A N D$ Kertas tertarik miring atau tersangkut setengah dan lampu indikator menyala $3 \mathrm{x}$ orange dan $1 \mathrm{x}$ hijau THEN mekanik printer bermasalah

16 IF printer termasuk Canon ip 1980 dan Canon ip 1880 AND Printer gagal menarik kertas AND Printer Blink 5/7x Orange 1x hijau THEN cartrige tidak terbaca salah satu atau keduanya

17 IF printer termasuk Canon ip 1980 dan Canon ip 1880 AND Printer gagal menarik kertas AND Printer blink 13x / 16x orange dan 1x hijau THEN "Ink Has Run Out"

18 IF printer termasuk Canon ip 1980 dan Canon ip 1880 AND Printer gagal menarik kertas AND Printer blink 4x/8x orange 1x hijau THEN mesin printer anda harus di reset menggunakan program

19 IF printer termasuk Ix 4000, Canon Ix 5000, Canon Ix 6000 AND Printer A3 berhasil menarik kertas $A N D$ hasil tidak ada atau kosong THEN tinta di dalam cartrige kosong

20 IF printer termasuk Ix 4000, Canon Ix 5000, Canon Ix 6000 AND Printer A3 berhasil menarik kertas AND Karakter aneh muncul / simbol-simbol bermunculan THEN Driver printer A3 anda bermasalah

21 IF printer termasuk Ix 4000, Canon Ix 5000, Canon Ix 6000 AND Printer A3 berhasil menarik kertas AND Cetakan kabur serta hasil bergaris (Cetakan tidak sempurna) $A N D$ Warna ada yang tidak keluar (tidak lengkap) THEN Cartrige mengalami masalah

22 IF printer termasuk Ix 4000, Canon Ix 5000, Canon Ix 6000 AND Printer A3 tidak bisa menarik kertas $A N D$ printer BLINK 3x THEN kertas tersangkut/papper jammed

23 IF printer termasuk Ix 4000, Canon Ix 5000, Canon Ix 6000 AND Printer A3 tidak bisa menarik kertas $A N D$ printer $B L I N K$ 4x THEN Tinta kosong atau tinta tidak di isi di cartridge

24 IF printer termasuk Ix 4000, Canon Ix 5000, Canon Ix 6000 AND Printer A3 tidak bisa menarik kertas AND printer BLINK 7x THEN "Multiple ink tanks of the same color installed"

$25 I F$ printer termasuk Ix 4000, Canon Ix 5000, Canon Ix 6000 AND Printer A3 tidak bisa menarik kertas $A N D$ printer BLINK 9x THEN printer tidak bisa membaca kamera

26 IF printer termasuk Ix 4000, Canon Ix 5000, Canon Ix 6000 AND Printer A3 tidak bisa menarik kertas AND printer BLINK 14x THEN Ink Tank Not Recognized

Aplikasi ini di bangun untuk platform Android, yang mana android ini adalah sebuah system operasi berbasis linux yang awalnya di kembangkan oleh Android inc yang kemudian di beli oleh Google dan sekarang di kembangkan oleh Google [15]. Aplikasi ini dapat di akses oleh admin dan user, dimana admin dapat melakukan penginputan gejala, kerusakan, serta rule yang ada. Sedangkan user hanya bisa melakukan diagnosa kerusakan saja. Untuk hasil diagnosa telah di ambil pengujian tiga data yang di perlihatkan pada Gambar 6, 7 dan 8 beserta pohon penelusuran.

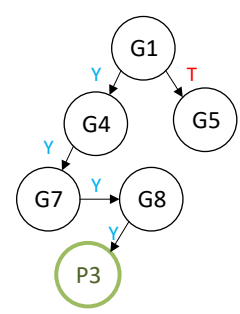




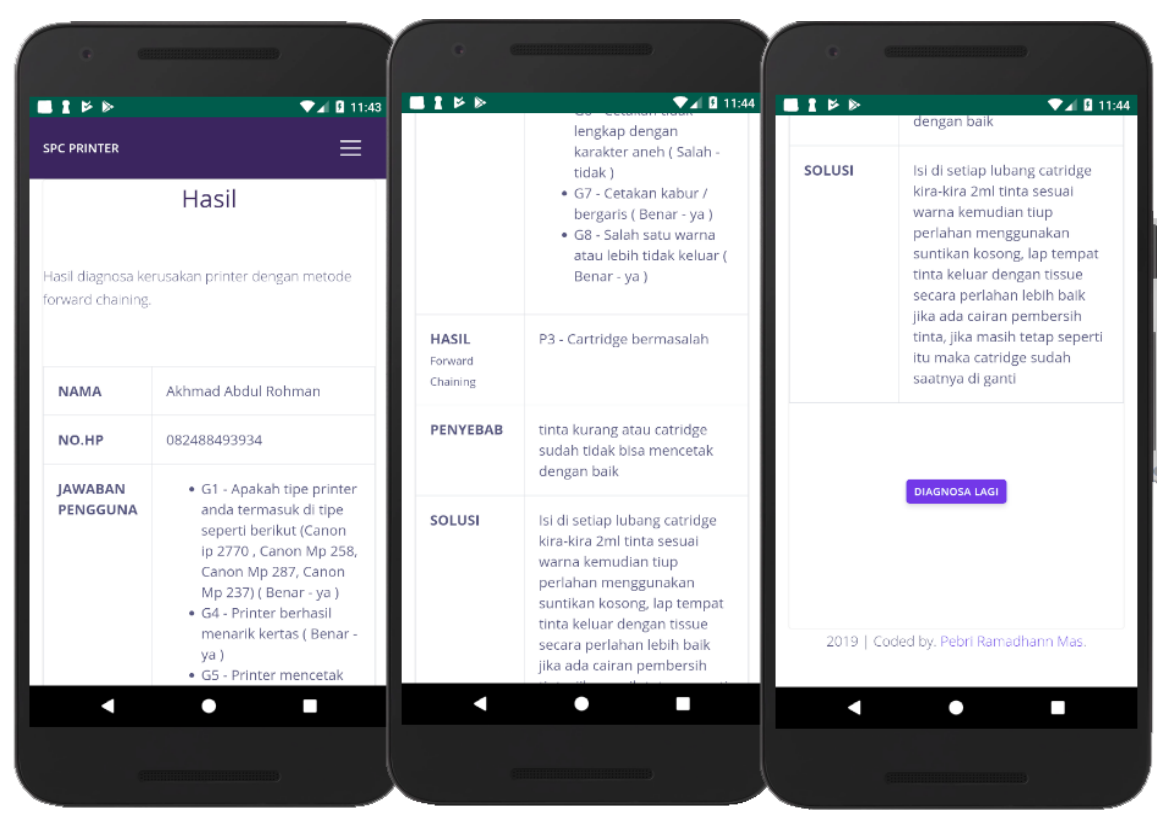

Gambar 6. Hasil diagnosa dan pohon penelusuran menuju hasil dengan gejala-gejala yang ada di aturan kerusakan semua terpenuhi

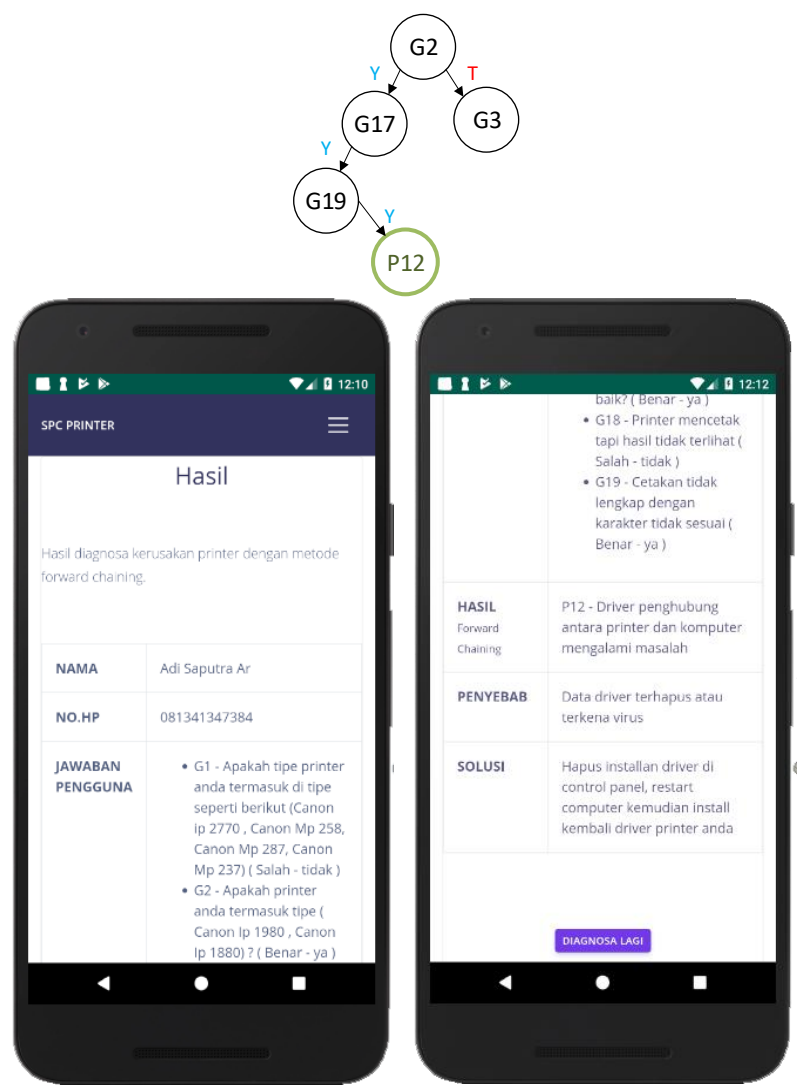

Gambar 7. Hasil diagnosa dan pohon penelusuran menuju hasil dengan gejala-gejala yang ada di aturan kerusakan semua terpenuhi

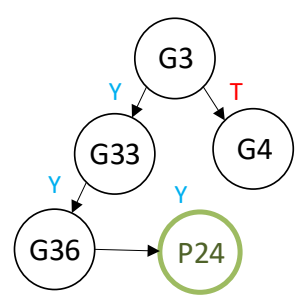




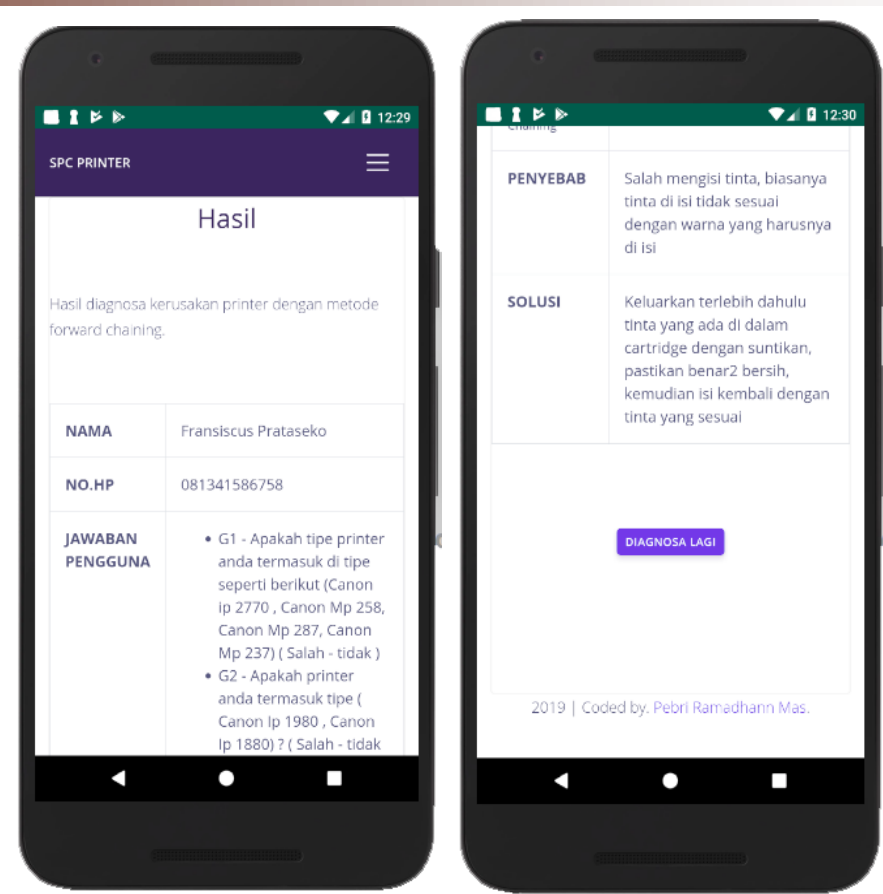

Gambar 8. Hasil diagnosa dan pohon penelusuran menuju hasil dengan gejala-gejala yang ada di aturan kerusakan semua terpenuhi.

\section{Kesimpulan dan saran}

Kesimpulan Berdasarkan pengujian dan analisis sistem pakar diagnosa kerusakan printer pada platform mobile dan web menggunakan metode Forward Chaining untuk mendapatkan hasil diagnosa, terlebih dahulu di dapatkan fakta-fakta gejala yang dialami printer pengguna setelah itu diolah melalui proses penalaran fakta-fakta menuju goal (tujuan) sehingga kerusakan printer di dapatkan sistem yang di bangun ini dapat mendeteksi 9 jenis printer yang berbeda milik pabrikan Canon dengan total memiliki 26 keruskan dan 38 gejala dengan tingkat akurasi 80\%. Saran yang dapat penulis berikan untuk pengembangan sistem pakar ini selanjutnya yaitu Penambahan jenis printer yang ada yang mana pada sistem pakar ini penulis hanya memasukan sembilan jenis printer dengan pabrikan Canon. Kemudian sistem pakar yang dibangun dapat dikembangkan lebih jauh dengan menggunakan metode Certainty Factor, Fuzzy Logic, Backward Chaining, dan lain-lain.

\section{Daftar Pustaka}

[1] D. W. Nugraha, "Sistem Pakar Untuk Mendiagnosa Kerusakan Perangkat Televisi menggunakan Metode Backward Chaining," J. Inform., 2015, doi: 10.21460/inf.2014.102.330.

[2] W. Supartini and H. Hindarto, "Sistem Pakar Berbasis Web dengan Metode Forward Chaining Dalam Mendiagnosa Dini Penyakit Tuberkulosis di Jawa Timur," KINETIK, 2016, doi: 10.22219/kinetik.v1i3.123.

[3] M. Hartono and E. N. M. Irsyad, "Sistem Pakar Pendeteksi Kerusakan Printer Berbasis Web menggunakan Algoritma Forward Chaining," STMIK AMIKOM, 2016.

[4] D. Anggraeni, "Sistem Pakar Diagnosa Kerusakan Pada Printer dengan menggunakan Metode Certainty Factor Pararel," 2017.

[5] D. Alfrido and T. K. Gautama, "Sistem Pakar Deteksi Kerusakan Sepeda Motor dengan Metode Forward Chaining," J. Tek. Inform. dan Sist. Inf., vol. 3, no. 3, pp. 618-636, 2017, doi: 10.28932/jutisi.v3i3.705.

[6] I. Akil, "Analisa Efektifitas Metode Forward Chaining Dan Backward Chaining Pada Sistem Pakar," None, vol. 13, no. 1, pp. 35-42, 2017.

[7] A. K. Syah and A. Y. Ananta, "Pembuatan Sistem Pakar Diagnosa Penyakit Pada Burung Puyuh Dengan Menggunakan Metode Forward Chaining," J. Inform. Polinema, vol. 2, no. 1, p. 1, 2017 , doi: 10.33795/jip.v2i1.46.

[8] B. Bernadhed, "Sistem Informasi Pelayanan Produk Berbasis Web Di Vendor Berkart!," Semin. Nas. Teknol. Inf. dan Multimed., 2013.

[9] P. Edu, "Pengertian Sistem Basis Data Menurut Para Ahli," 2015. [Online]. Available: https://dosenit.com/kuliah-it/database/pengertian-sistem-basis-data-menurut-para-ahli. [Accessed: 16-Apr-2017]. 
[10] Enterprise, MySQL Untuk Pemula. Jakarta: Elex Media Komputindo, 2014.

[11] B. Sinaga, P. M. Hasugian, and A. M. Manurung, "Sistem Pakar Mendiagnosa Kerusakan Smartphone Android menggunakan Metode Certainty Factor,” Inform. PELITA Nusant., 2018.

[12] N. Badariah, D. Sugiarto, and C. Anugerah, "Penerapan Metode Failure Mode and Effect Analysis ( FMEA ) dan Expert System (Sistem Pakar)," Jur. Tek. Ind. Fak. Teknol. Ind. Univ. Trisakti, vol. 1, no. November, pp. 1-10, 2016.

[13] P. A. Saputro and C. Supriyanto, "Analisis Metode Forward Chaining Dalam Sistem Pakar Diagnosa Penyakit Pada Hewan Sapi,” Res. J. Pharm. Technol., vol. 5, no. 9, pp. 1197-1200, 2012.

[14] A. A. Rismayadi, "Kerusakan Hardware Komputer,” vol. 3, no. September, pp. 41-46, 2016.

[15] F. H. M. Ichwan, "Pengukuran Kinerja Goodreads Application Programming Interface (API) pada Aplikasi Mobile Android,” J. Informatika Itenas, 1978. 